\section{REASON AND REALITY REVISITED}

\author{
Evelyn Pluhar \\ Pennsylvanio Stote University \\ Foyette Compus
}

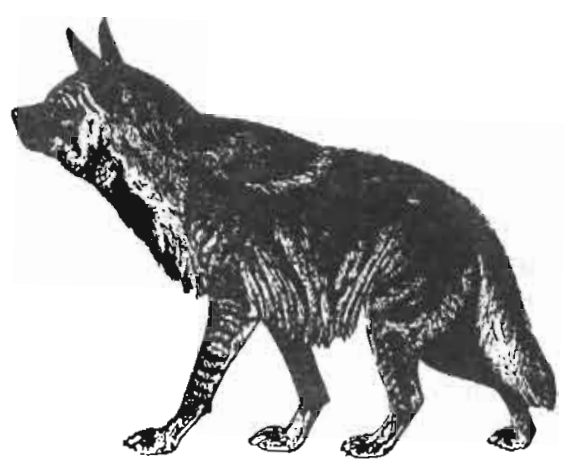

Philosopher Alan Gewirth holds that reflective, rational agents are logically compelled to accept and respect the rights of others. I have argued that his reasoning implies that both so-called "marginal" humans and many nonhuman animals must be included in the sphere of morally considerable beings. 2 Frank De Roose has taken issue with Gewirth's purported justification of morality in his recent article. "Pluhar on Methods of Justification." 3 Citing several other critics of Gewirth, De Roose argues that logic does not dictate the shift from agency to moral agency. I shall argue here that this critique of Gewirth is mistaken, although it is quite true that logic, in an important sense, is not a guarantee of morality.

Let us begin with a brief sketch of Gewirth's line of reasoning. Moral codes are action guides and must be understood within the context of agency. Only agents, who (i) are able to control their own behavior, (ii) have knowledge of the relevant proximate circumstances of their actions, and (iii) have purposes they wish to fulfill, 4 are capable of

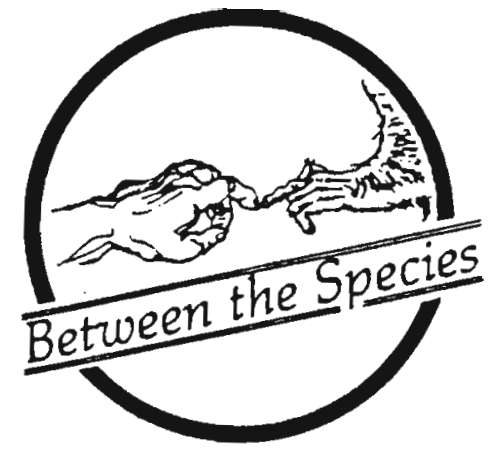

action. When we take the point of view of ariy particular reflective, rational agent, Gewirth argues, we can see how that agent logically must accept the view that others are as worthy of moral concern as she believes herself to be. (Of course, he does not claim that agents all actually go through the steps of the argument which follows. He is offering a rational reconstruction, not a psychological thesis.)

First, the reflective agent can see that action of any kind has two necessary preconditions or "generic features": (1) the ability to have purposes or goals, and (2) the freedom which is required to pursue those goals. In order to have goals, one must in turn be alive, have a certain minimal quality of life, and have certain basic mental and physical capabilities. Gewirth combines these requirements for the first generic feature of action under the heading of "well-being." 5 Thus, the reflective agent who wants to pursue her goals must also value her well-being and freedom, and hold that they are good:

(1) "My freedom and well-being are necessary [i.e., are required for action in pursuit of goals] goods." 6

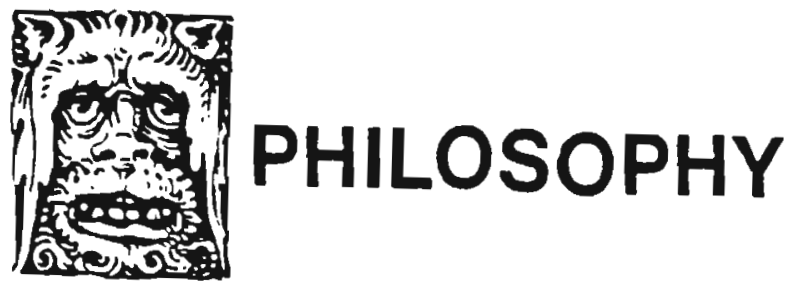


Note that Gewirth is not claiming that the agent's freedom and well-being are good; his point is that the reflective agent must hold them, as generic features of action, to be good. Even a self-destructive agent contemplating suicide must value the freedom and well-being needed at that moment to carry out her purpose.

The agent's realization that her freedom and well-being are requirements for the achievement of her goals leads her to prescribe that

(2) "I must have freedom and well-being." 7

This prescriptive claim in turn leads the agent to claim that she is entitled to freedom and well-being:

\section{(3) "I have rights to freedom and well-being." 8}

Note once again that Gewirth is not arguing that the agent has these fundamental, "generic," rights; he is saying that she holds or accepts that she does, as an agent who wishes to pursue her goals.

Gewirth uses an indirect proof to show that the agent logically must claim these generic rights for herself. If she were to deny (3), she would also have to deny that

(4) "All other persons ought at least to refrain from removing or interfering with my freedom and well-being." 9

But if she denies (4), the agent must accept the following substitute premise:

(4') "Others persons may (i.e., it is permissible that other persons) remove or interfere with my freedom and well-being." 10

However, (4') contradicts (2): "I must have freedom and well-being." Since the agent gua agent must accept (2), she must then deny (4'). Since (4') follows from the rejection of (3), the agent must then claim that she has rights to the preconditions for agency.

No, so far the agent has not made a moral claim. The normative claim in (3) is prudential, because it concerns the furthering of her interests alone. The shift from the prudential to the moral point of view, according to which athers' interests count loo, begins with the agent's justification of the rights claim made in (3). As Gewirth points out, rightsclaims, as opposed to bald demands, are claims that one is entitled to or due certain behavior on the part of others; hence, they need to be warranted."11 The agent who reflects on her rights-claim realizes that it is warranted by the simple fact that she has purposes she wants to fulfill; i.e., she is "a prospective purposive agent." This is the most basic "practical justifying reason" which can ever be given. As one who wishes to act, she must claim or advocate that she is entitled to the conditions which make action possible. Thus, she accepts

(5) "I have rights to freedom and well-being because 1 am a prospective purposive agent." 12

The next stage in the shift from the prudential to the moral point of view comes with the acceptance of the principle of universalizability:

(6) "If the having of some quality $Q$ is a sufficient condition of some predicate P's belonging to some individual $S$, then $P$ must also belong to all other subjects that have Q." 13

It follows, Gewirth argues, that

(7) "All prospective purposive agents have rights to freedom and well-being." 14

This is a moral claim, not merely a prudential one, because it implies that others besides oneself are entitled to have their freedom and well-being respected. It grounds what Gewirth calls "The Supreme Principle of Morality":

(8) "Act in accord with the generic rights of your recipients as well as of yourself." (the Principle of Generic Consistency [PGC])15

Our sketch of Gewirth's argument is now complete: If he is right, reflective agents are compelled by no less than logical consistency to take 
the moral point of view. Gewirth's reasoning has enormously important implications. It implies that the rational agent logically must accord (prima facie) rights of freedom and well-being to every individual who has purposes he or she wants to fulfill. I have argued elsewhere that even those agents who are intellectually incapable of reasoning through the steps which lead to the PGC must have these rights accorded to them. ${ }^{16}$ Agents who cannot be moral agents require the preconditions of agency in order to act, just as intellectually better endowed agents do. It follows that many animals, namely those who exhibit what Tom Regan has called "preference autonomy," 17 would also logically have to be accorded rights.18 Finally, beings who have preferences but lack the mental or physical ability to satisfy them, would at least have to be accorded the right to well-being, even though their freedom might have to be limited for their own and others' protection. 19 Very young or "marginal" humans would thus also be morally considerable. Agents who deliberately refuse to hold that these others have rights are guilty of the most glaring logical fallacy of all, if Gewirth's line of reasoning is correct: selfcontradiction.

But is Gewirth's line of reasoning correct? Many objections have been raised against it. Gewirth anticipated and answered most of these objections himself in Reason and Morality. Some additional abjections have been raised against it by critics and addressed by Gewirth in the most recent book on his views. 20 Frank De Roose has now argued that aithough Gewirth has indeed correctly shown that reflective agents must claim the rights to freedom and well-being for themselves, he has not shown that agents must hold that others have these rights. 21

Paraphrasing R.M. Hare, De Roose charges that Gewirth is himself guilty of a logical fallacy: the equivocation of "having a right" with "clalming a right." 22 From the "relatively uncontroversial" thesis that every reflective agent must claim rights for herself, De Roose charges, Gewirth moves, via the (also presumably uncontroversial) principle of universalizability, to "all prospective agents who have purposes they want to fulfill have the rights of freedom and well-being." 23 De Roose quotes an early critic of Gewirth, Adina Schwartz, on this seemingly fatal flaw:

Gewirth has only shown that each agent must claim rights for him/herself on prudential grounds. Therefore, each agent is only logically bound to admit that all other agents have sound prudential reasons for claiming those same rights for themselves. 24

Recognizing that others claim the rights to freedom and well-being is not tantamount to according them those rights. Hence, the rational agent is not inconsistent if she refuses to take the moral point of viow.

De Roose points out that R.M. Hare later pressed much the same objection:

For if all he had shown was that an agent must claim that there is a prudential requirement on him to seek the necessary conditions for achieving his purposes, the universalization of this claim would only yield the claim that there is a prudential requirement on other similar agents in similar situations to seek the necessary conditions for achieving their purposes. 25

Clearly, the latter claim is not moral at all; it is as resoundingly prudential as the claim from which it was universalized.

The charge that Gewirth has failed to bridge the gap between prudence and morality, pressed by Schwartz, Hare, and De Roose, is actually mistaken. However, in his reply to Hare, 26 Gewirth fails to show that he can escape that charge. He agrees with Hare that (a) "there is a prudential requirement on [an agent] to seek the necessary conditions for achieving his purposes" entails (assuming universalizability). (b) "there is a prudential requirement on other similar agents to seek the necessary conditions for achieving their purposes." He then argues that (b), when said by the agent referred to in (a), is actually a moral judgment, because it "takes favorable account of the interests of persons other than or in addition to (the original agentl." 27 But this cannot be made out. An agent 
who says that it is in the interests of other agents to seek freedom and well-being takes neither favorable nor unfavorable account of the interests of those other agents; he or she simply makes an observation. Hitler, while no doubt realizing that it was in the interests of his death camp victims to have freedom and well-being, was not exactly "taking fovorable account" of their interests whenever this thought occurred to him!

Gewirth, in trying to hoist Hare on his own prudential petard, concedes too much in accepting Hare's framework for discussion. He takes a step in the right direction when he stresses the importance of taking the agent's standpoint, but he does not put this step in the correct context. The claim to be universalized is the gaent's, not an outside observer's description of the agent's claim. Hare (and Schwartz before him) assumes that "the agent claims the rights of freedom an well-being for herself on prudential grounds" must be Gewirth's prudentlal starting point on his path to the moral point of view. This starting point can indeed not be universalized into a moral claim. However, the actual claim to be universalized is the agent's claim that "I have the rights to freedom and well-being because I am a prospective purposive agent" (step 5 in our earlier sketch of Gewirth's argument). When this claim is universalized we get step 7: "all prospective purposive agents have the rights to freedom and well-being." This is a moral judgment because, by making it, the agent thereby accords rights to others. She does not merely observe that others claim rights to freedom and well-being because it is in their interests to do so. The novelty and force of Gewirth's argument is due to his insistence that we take the agent's standpoint throughout. He does not need to ghow that the original agent has rights or that all agents have rights; he need only show that the reflective agent must hold that she has rights. Once he has shown this (and De Roose himself calls this step "relatively uncontroversial"), universalization leads to the agent's holding that others with purposes they want to fulfill also have rights. The critics' mistake is to confuse the agent's claim with someone else's report of that claim.

De Roose's formulation of the objection allows us to see this mistake more clearly. He grants that Gewirth shows that "all [reflective] agents must claim for themselves the right to freedom and wellbeing." The agent, then, is said to judge that "I claim for myself rights to freedom and well-being." He rightly argues that "From [this] judgment ... one can with the help of the logical principle of universalizability only infer a universalized prudential judgment and not a moral judgment," 28 presumably the judgment that "other prospective agents similar to myself claim rights of freedom and well-being for themselves." But this misidentifies the judgment to be universalized. The statement that "all [reflective] agents must claim for themselves rights to freedom and well-being" does not imply that the agent thinks to herself "I claim the rights to freedom and well-being." This adds an extra layer of reflection which need not at all be present. One claims the rights to freedom and well-being for oneself by saying or thinking "I have the rights to freedom and woll-being." This statement is the rights-claim in question! Claiming a right and having a right are indeed two different matters. Since the agent must hold that she has rights, by Gewirth's argument, not merely that she claims rights, the judgment to be universalized is "I lon the grounds that I am a prospective purposive agent] have the rights to freedom and well-being." Gewirth does not commit the fallacy of equivocating "having a right" and "claiming a right" at all. On the contrary, the contention that "S claims rights" entails that S must think "I claim rights" commits the intentional fallacy. The third-person report of the agent's judgment is illicitly imported into the judgment itself. Gewirth's reasoning, therefore, has not been refuted by the objection Schwartz, Hare, and De Roose have raised. Unless he can be shown mistaken in some other respect, Gewirth appears to have shown that the rational, reflective agent logically must hold that others in addition to herself have basic moral rights.

Unfortunately, the above does not imply that agents with normal mental capacities will respect the rights of others. De Roose is skeptical of Gewirth's claim that "the transition from the prudential to the moral and social is . . not motivational but logical." 29 Even if Gewirth, as I 
have argued, has successfully shown that consistency requires the agent to hold that others have rights, skepticism about the moral behaavior of agents is warranted. The agent must also be motivated or inclined to abide by the dictates of reason. She may be perfectly able to see that others have the rights that she claims for herself, and yet refuse to respect them. Plato notwithstanding, one may knowingly do evil: immoralists can exist.

Gewirth raises a form of this objection himself. If, as David Hume has claimed, reason alone can compel to action, what else can motivate the agent to act morally? Why should the agent who realizes that she is logically committed to the rights of others act so as to respect those rights?30 Gewirth's answer here is that the agent "rationally must accept the PGC because it is entailed by another judgment he accepts." $3 i$ He adds that "by virtue of the PGC's being rationally justified, the rational agent is in fact motivated to accept it, since, being rational, he accepts what is rationally justified." 2 Well and good, but not all agents are thoroughgoingly rational. That is precisely the problem! Gewirth's reply plainly leaves any immoralists unscathed.

Another group of problematic agents reject reason at an even earlier point than immoralists. They, while fully believing that they are entitled to rights to freedom and well-being, refuse to universalize beyond their own cases. These are the amoralists. Gewirth has devoted considerable attention to this group, beloved by critics such as Hare 33 He succeeds in showing that the critics err in their claim that amoralists do not contradict themseives. Nevertheless, amoralists exist; logic does not overpower their lack of concern for others.

The bad news (and not just for teachers of logic) is that agents are very frequently illogical. A number of social scientists recently have conducted studies which indicate that illogical, inconsistent processing of information is extremely common.34 In view of this depressing fact, how can one expect agents not to be amoralists or immoralists? Why should they care about anyone other than themselves?

These questions are hardly new; as De Roose observes, we have been seeking the motivation for taking the moral, as opposed to the exclusively prudential, point of view for a very long time, 35 Psychology is needed to provide the answers, if indeed there are any. Hume anticipated psychologists when he argued that "feeling" rather than reason alone leads us to make moral distinctions.36 While we may doubt the mechanism he proposes for the operation of "the moral sense," it is difficult to deny that feeling has a central role. Simply put, caring about others motivates our moral concern for them. Psychologists who study moral development have amassed much evidence for the caring trait; it begins to appear almost as early as one's concern for oneself does. Jerome Kagan argues that empathy, the ability to imagine oneself in another's place, normally appears around the second year of life regardless of one's culture, and it immediately reveals itself in some of the child's actions. 37 Lawrence Kohlberg places the development of a caring orientation in childhood as well.38 We do not refrain from torturing innocents simply because to do 50 violates rights which we are logically compelled to grant; we refrain because we are emotionally incapable of inflicting undeserved agony. We do not need to read Gewirth to become convinced that we should try to help starving humans in Ethiopla; seeing their tortured, hopeless eyes and emaciated bodies is quite sufficient to spur our action. Nor do we need to reason to the PGC to realize that veal calves, for example, are tortured innocents, and that to eat them is an abomination. In short, we do care about others. This is, apparently, a trait we share with many nonhuman animals. 39 Human immoralists and amoralists have somehow fallen short or been "arrested," as a psychologist might say, in their moral development.

Why, then, rely upon reason in moral matters? Why not trust our feelings instead? Conceptualizing the PGC is not necessary for us to take the moral point of view, and those who refuse to go beyond prudence are, one might hold, not going to find it sufficient. Must we not try to reach their emotions instead? Do not tears win more moral battles than appeals to consistency?

Perhaps they do, but the sad fact is that reliance upon feelings alone has led to many a moral abomination. Bigots are filled with fervent and totally illogical conviction. To very loosely 
paraphrase Immanuel Kant, reason without emotion may be impotent, but emotion without reason is blind. Without reason, although it is not a guarantee, one has little chance of avoiding delusion, prejudice, and arbitrariness. Anyone to whom truth and fairness is important should acknowledge the immense value of rationality. Properly understood, reason should inspire our passionate devotion.

Herein lies the great value of Gewirth's enterprise. He has shown that what many of us almost automatically feel to be true--that individuals who care about what happens to them have just as much right to freedom and well-being as we do--can be justified in the most stringent way. Some ears may well be deaf to the twin appeals of reason and emotion, but others can be reached. More than this we cannot ask.

\section{NOTES}

1. Alan Gewirth, Reason and Morality (Chicago: U. of Chicago Press, 1978). Gewirth amplifies his views further in Human Rights: Essays on Justification and Applications (Chicago: $U$. of Chicago Press, 1982). Gewirth's views are critically examined by a number of ethical theorists in Edward Regis, Jr. (ed.), Gewirth's Ethical Rationalism (Chicago: U. of Chicago Press, 1984). See Gewirth's extensive "Replies to My Critics," in the same volume (pp. 192-255).

2. Evelyn Pluhar, "Moral Agents and Moral Patients," Between the Species IV (1), 1988, pp. 32-45. For my discussion of Gewirth see pp. 38-40 and 43-45.

3. Frank De Roose, "Pluthar on Methods of Justification," Between the Specjes IV (4). 1988, pp. 255-59.

4. Gewirth, Reason and Morality 00. cit., p. 27.

5. Ibid., p. 64.

6. Gewirth, "Replies to My Critics," op. cil., pp. 204-5. I have omitted some steps which are not essential to this discussion, so (1) is actually Gewirth's (3).

7. Ibid, p. 205.

8. Lbid.

9. Ibid.

10. Ibid. p. 206.

11. Ibid., p. 210.

12. Ibid. On the practical nature of this justification, see Beason and Morality, p. 72.

13. Ibid.

14. Ibid. These are prima facie rights, of course. An agent who threatens an innocent's well-being or freedom might have to have her right to freedom curtailed, for example.

15. Lbid. p. 197. See Chapter Three of Reason and Morality for a full discussion of the PGC.

16. "Moral Agents and Moral Patients," gp. cit., p. 39. Gewirth himself sometimes suggests that beings who cannot reflect on the preconditions of action cannol be agents (and hence could not be covered by the PGC). I have argued that this is a mistake (p, 44).

17. Tom Regan, The Case for Animal Rights (Berkeley: U. of California Press, 1983), pp. 8486.

18. Although Gewirth argues that animais must be accorded some moral consideration, he denies that they can occupy the same moral position as normal or "marginal" humans. See p. 40 of my "Moral Agents and Moral Patients" for a refutation of this view.

19. Reason and Morality oo. cit., pp, 142-43. He amplifies his views in "Replies to My Critics," op. 
cit., pp. 225-27.

20. Regis, Gewirth's Ethical Rationalism, op. cit.

21. De Roose, "Pluhar on Methods of Justification," op. cit.

22. Ibid, p. 256.

23. ibid.

24. Adina Schwartz, "Review: Reason and Morality" Philosophical Review 88 (1979), p. 656 (quoted by De Roose on p. 256).

25. R.M. Hare, "Do Agents Have to Be Moralists?," Gewirth's Ethical Rationalism, op. cit., pp. 52-58. See p. 56.

26. "Replies to My Critics," op. cit., pp. 211-12.

27. Ibid., p. 211 . Emphasis mine.

28. De Roose, op. cit., p. 256.

29. Ibid., p. 257

30. Reason and Morality op. cit., Dp. 190-96.

31. Ibid., p. 193.

32. bid., p. 195.

33. R.M. Hare, "Do Agents Have to Be Moralists?," op. cit.

34. "How Dare We?," Science News v. 132, July 1987. pp. 57-59.

35. De Roose, op cit., p. 257.

36. David Hume, A Treatise of Human Nature (London: Oxford U. Press, 1888), edited by L.A. Selby-Bigge, Book III, Part I, pp. 455-476. See also "Part 1: The Moral (In)Significance of Reason" in S.F. Sapontzis' Morals, Reason, and Animals
(Philadelphia: Temple U. Press, 1987), for arguments about reason's limitations in moral contexts.

37. Jerome Kagan, The Nature of the Child (New York: Basic Books, 1984).

38. Lawrence Kohlberg, "Moral Stages and Moralization," The Psychology of Moral Development (San Francisco: Harper \& Row, 1984). However, he takes the caring orientation to be a rather primitive one. He has been roundly criticized for this by Carol Gilligan, In a Different Voice (Cambridge, Mass.: Harvard U. Press, 1982).

39. Examples of altruistic behavior, even towards members of other species, have been welldocumented by scientists. J. Rachels gives a particularly powerful series of examples of such behavior in his "Do Animals Have the Right to Liberty?," Animal Rights and Human Obligations, Tom Regan and Peter Singer, eds. (Englewood Cliffs, N.J.: Prentice-Hall, 1976), pp. 215-17. Of course, no one claims that animals are consistently or even largely motivated by concern for others; they are not saints. Neither are most moral agents.

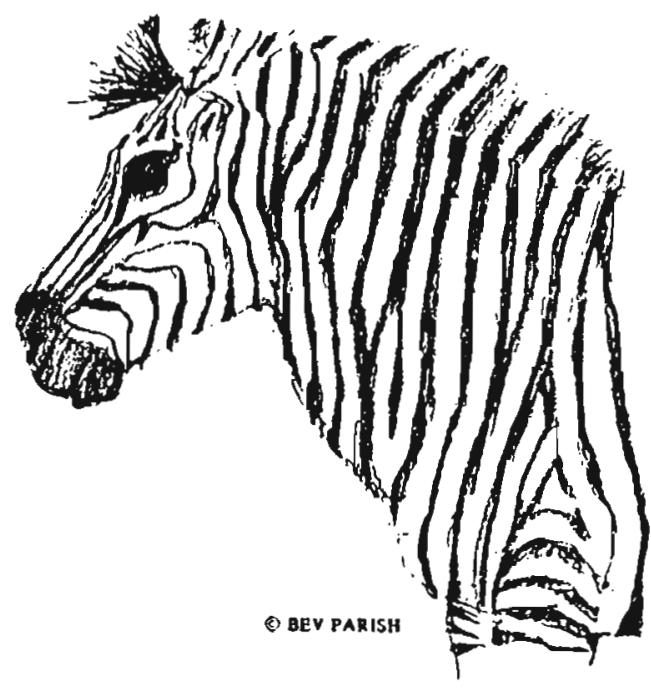

